\title{
Prognostic Factors for Conversion to Arthroplasty after Hip Arthroscopy. Review of the Literature
}

\author{
Roberto Seijas, MD, PhD ${ }^{1,2,3}$ David Barastegui, MD, PhD ${ }^{1,2,3,4}$ Ferran Montaña, MS 1,3 \\ Marta Rius, MD ${ }^{1,2,4}$ Xavier Cuscó, MD ${ }^{1,2}$ Ramón Cugat, MD, PhD ${ }^{1,2,4}$
}

\author{
${ }^{1}$ Instituto Cugat Hospital Fundació García Cugat Quiron, Barcelona, Spain \\ 2 Fundació García Cugat, Garcia, Cugat \\ ${ }^{3}$ Medicine Department, Universitat Internacional de Catalunya, \\ Barcelona, Spain \\ ${ }^{4}$ Mutualitat Catalana de Futbolistas (FCF)-Real Federación Española \\ de Futbol, Madrid, Spain
}

Surg J (NY) 2021;7:e374-e380.

\author{
Abstract

\section{Keywords} \\ - hip arthroscopy \\ - prognostic \\ - prognostic factor \\ - total hip replacement \\ - conversion \\ - arthroplasty
}

Address for correspondence Roberto Seijas, MD, PhD, Instituto Cugat Hospital Quiron Barcelona, Plaza Alfonso Comín 5, 08023 Barcelona, Spain (e-mail: roberto6jas@gmail.com).
Arthroscopic techniques in the treatment of femoroacetabular impingement have experienced an exponential increase over recent years for both diagnosis and treatment. The main risks with treatment are poor clinical outcomes and the conversion to prosthesis. Better knowledge and understanding of the various risk factors leading to prosthesis will improve patient selection for arthroscopic treatments rendering better results. The published papers that have been selected are related to series of hip arthroscopies with risk factors that lead to total hip arthroplasty (THA), in the PubMed database, without a time limit, number of patients, or follow-up time. We selected over 302 papers, 19 papers that show risk factors for conversion to THA. The main risk factors found were femoral chondropathy grade III/IV (relative risk 58.112 times increased), acetabular (20-2.96 times), an articular space $<2 \mathrm{~mm}$ (39-4.26 times), age (14.6-1.06 times), Tönnis 2 in radiographic studies (7.73-3.1 times), obesity (5.6-2.3 times), and osteoarthritis (4.6-2.4 times). There are several risk factors which in an isolated way, highly increase the risk of THA. Some of them have a clear relationship (chondropathy, reduced joint space, Tönnis 2, and osteoarthritis). Based on the review we observed that the elements that are most associated with a conversion to THA after a hip arthroscopy are a high degree of femoral and acetabular chondropathy, a reduced joint space below $2 \mathrm{~mm}$, older age, Tönnis 2, obesity, and hip osteoarthritis.
Osteoarthritis of the hip has a significant clinical affectation in today's population producing pain and functional alterations. $^{1,2}$ It is estimated that between 10 and 19 million inhabitants of the United States ${ }^{2}$ are affected and management involves an expenditure of approximately 24 billion USD in Australia each year. ${ }^{2}$

received

February 23, 2020 accepted after revision January 13, 2021
DOI https://doi.org/ $10.1055 / \mathrm{s}-0041-1741512$ ISSN 2378-5128.
Given this impact, early treatment is aimed at improving the quality of life of these patients and consequently reducing a very high health expenditure. ${ }^{2,3}$

Different studies have linked hip osteoarthritis with femoroacetabular impingement and postulate that treatment can alter at least the symptomatic impact for these patients,

\section{(C) 2021. The Author(s).}

This is an open access article published by Thieme under the terms of the Creative Commons Attribution License, permitting unrestricted use, distribution, and reproduction so long as the original work is properly cited. (https://creativecommons.org/licenses/by/4.0/)

Thieme Medical Publishers, Inc., 333 Seventh Avenue, 18th Floor, New York, NY 10001, USA 
although long-term studies are needed to see if it modifies the course of the disease. ${ }^{2,4-6}$

Hip arthroscopy has proven effective in solving coxofemoral joint problems, especially in femoroacetabular impingement. ${ }^{7}$ The use of this technique has seen exponential growth in the last decade. In the United States, between 2004 and 2009 it increased 365\%, between 2006 and 2010 600\%, and between 2007 and 2011 250\%, ${ }^{9}$ while in the United Kingdom between 2002 and 2013 the increase was $727 \%{ }^{10}$ This increase has been observed in those under 30, with an increase of 355\% (between 2007 and 2011), but also in those over 60 (200\% in the same period). ${ }^{9}{ }^{9} 11$ It is estimated that the annual increase for this technique could be as much as $15 \%^{2,12}$

There are several justifications for this increase, such as: advances and improvements in the technical aspect, improvements in the indications, ${ }^{9,13-15}$ better results in young patients and athletes, ${ }^{16}$ greater exposure of the population to a greater number of hours of sport, ${ }^{9}$ and the greater demand by the population to maintain their standard of living as well as that of sports. ${ }^{9}$

Another factor to take into account is the increase in the spectrum of indications, such as femoroacetabular impingement, labral lesions, and cartilaginous lesions, with the latter being the most frequent to be treated by this technique. ${ }^{17-20}$

Hip arthroscopy has demonstrated its efficacy both in the short ${ }^{13,21}$ and long term, ${ }^{20,22,23}$ with regards to clinical improvement, with good and excellent results in pathologies such as FAI and labral lesions, ${ }^{16,24-29}$ without degeneration in studies published at longer follow-up. ${ }^{7}$

But this increase in indications also leads to an increase in the number of revision surgeries, including conversions to total hip arthroplasty (THA) ${ }^{30,31}$ In fact, the main reason for re-operating after an arthroscopy is to perform a conversion to THA. ${ }^{26}$ A percentage of these conversions to THA (and hip arthroscopy failure) should be considered attributable to an incorrect preoperative diagnosis or poor patient selection. ${ }^{32,33}$

The preoperative detection of factors that can provide us with information regarding the viability of our surgical procedure $^{32,33}$ is vital to increase the success rate of this technique.

This study is based on the systematic review of published studies with the objective of identifying which prognostic factors are related to a higher rate of conversion to THA after hip arthroscopy.

\section{Material and Methods}

A bibliographic search is performed using the keywords: Hip Arthroscopy, Hip Replacement Arthroplasty, Total Hip Replacement, Prognosis, Risk Factors, in different combinations in the PubMed database in April 2019.

The inclusion criteria were those articles that included risk factors leading to THA, with no follow-up limit or limit on the number of participants. The exclusion factors were articles that did not clearly expose the risk factors, opinion articles or editorials, isolated cases or systematic reviews that did not provide their own series.

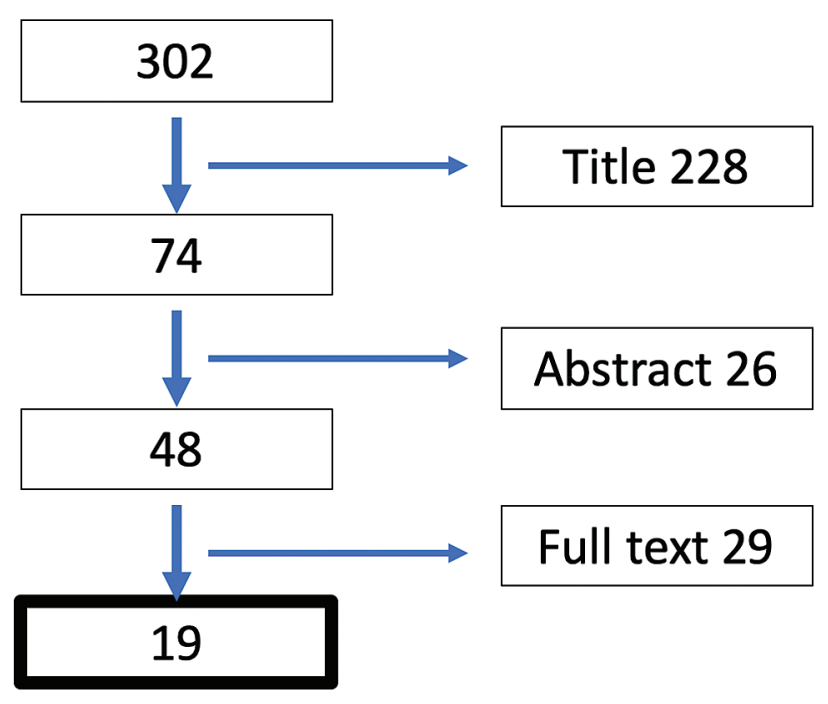

Fig. 1 Flowchart of the study, where the studies were eliminated according to the title, the summary, and after reading the full text.

Initially, 302 articles were selected from which 74 were selected after reviewing the titles, eliminating isolated clinical cases, opinion articles, and articles unrelated to our question. Twenty-six articles were withdrawn from the review because they did not adhere to the topic defined when reviewing the summary. The 48 remaining articles were reviewed in full text format and once again eliminating the articles that did not fit our study, with the final sample of 19 articles that were selected to perform this review (-Fig. 1).

\section{Results}

The articles included in this study present case series with a considerably varied sample, with series from 30 cases up to 8,827 . This is due to the larger series being obtained from database reviews, while the shorter series are series performed by a specific group of surgeons reviewing their own cases.

Risk factors showed significant differences in each study and a statistical calculation of the relative risk was performed. In some of the studies this calculation was not performed and therefore is not reflected in the table. - Table 1 shows the data collected from the 19 articles.

Risk factors are also not always defined equally (-Table 2 ). Age is considered in some works as a dichotomous variable, above or below a figure, which can be 40,50 , or 60 years. ${ }^{9}, 11,12,34-39$ Some studies find that the risk is progressive and does not depend on a limit value, but it is an increasing risk as one grows older. ${ }^{39-41}$

Other variables, such as osteoarthritis, may be defined by radiological criteria or not included in the work as such, because the data that is linked to the operated patient is analyzed. . $^{911,12,30,35,39}$ Some of the works take the reduced articular space into account, $3,6,40,42,43$ some based on the Tönnis classification, ${ }^{42,44,45}$ and some works are based on the state of the cartilage, according to the Outerbridge classification. $34,37,41,45$ 
Table 1 Summary of the selected articles, with the risk factors to THA after an arthroscopy and the relative risk they presented in each work

\begin{tabular}{|c|c|c|c|c|}
\hline Author (Ref) & Year & $N$ & Risk factor & RR \\
\hline Kaldau et al (34) & 2018 & 84 & $\begin{array}{l}\text { Age }>40 \text { y } \\
\text { Cartilage lesion }\end{array}$ & $\begin{array}{l}- \\
-\end{array}$ \\
\hline Kester et al $(35)^{c}$ & 2018 & 3,957 & $\begin{array}{l}>60 \text { y } \\
\text { Osteoarthritis } \\
\text { Tobacco } \\
\text { Obesity } \\
\text { Female } \\
\text { Less skilled surgeon }\end{array}$ & $\begin{array}{l}3.4 \\
2.4 \\
1.9 \\
5.6 \\
1.8 \\
1.9\end{array}$ \\
\hline McCarthy et al (12) & 2018 & 989 & $\begin{array}{l}\text { Osteoarthritis } \\
\text { Age }>50 \text { y } \\
\text { Prior arthroscopy }\end{array}$ & $\begin{array}{l}4.6 \\
3.8 \\
2.6\end{array}$ \\
\hline Perets et al (45) & 2018 & 94 & $\begin{array}{l}\text { Tönnis }>0 \\
\text { Femoral Outerbridge }>2\end{array}$ & $\begin{array}{l}3.1 \\
12\end{array}$ \\
\hline Haefeli et al (50) & 2017 & 52 & $\begin{array}{l}\text { LCE angle }>33 \text { degrees } \\
\text { Acetabular index }<3 \text { degrees }\end{array}$ & $\begin{array}{l}4.6 \\
-\end{array}$ \\
\hline Menge et al (40) & 2017 & 145 & $\begin{array}{l}\text { Age } \\
\text { Space }<2 \mathrm{~mm} \\
\text { Acetabular microfractures }\end{array}$ & $\begin{array}{l}3.06 \\
4.26 \\
2.86\end{array}$ \\
\hline Redmond et al (41) & 2017 & 792 & $\begin{array}{l}\text { Age } \\
\text { mHHS low } \\
\text { Femoral anteversion } \\
\text { Revison surgery } \\
\text { Outerbridge II } \\
\text { Outerbridge III } \\
\text { Outerbridge IV } \\
\text { Acetabuloplasty } \\
\text { Lack of femoroplasty }\end{array}$ & $\begin{array}{l}1.06 \\
0.98 \\
0.97 \\
2.4 \\
2.23 \\
2.17 \\
2.96 \\
1.83 \\
0.62 \\
\end{array}$ \\
\hline Bedard et al $(11)^{c}$ & 2016 & 1,728 & $\begin{array}{l}\text { Age }>50 \\
\text { Chondroplasty } \\
\text { Osteoarthritis }\end{array}$ & $\begin{array}{l}3.18 \\
3.5 \\
3.8\end{array}$ \\
\hline Chandrasekaran et al (44) & 2016 & 935 & Tönnis 2 & 7.73 \\
\hline Herrmann et al (30) & 2016 & 99 & $\begin{array}{l}\text { Osteoarthritis } \\
\text { Joint space }\end{array}$ & $\begin{array}{l}-^{\mathrm{b}} \\
-{ }^{\mathrm{b}}\end{array}$ \\
\hline Schairer et al (39) ${ }^{c}$ & 2016 & 7,351 & $\begin{array}{l}\text { Age }>60 \text { (although }>40 \text { risk increases) } \\
\text { Obesity } \\
\text { Osteoarthritis } \\
\text { Centre volume }>10 / y\end{array}$ & $\begin{array}{l}14.33 \\
2.43 \\
2.3 \\
0.76\end{array}$ \\
\hline Malviya et al $(36)^{c}$ & 2015 & 6,395 & $\begin{array}{l}\text { Age }>50 \\
\text { Female sex }\end{array}$ & $\begin{array}{l}4.65 \\
1.68\end{array}$ \\
\hline Redmond et al (38) & 2015 & 30 & $\begin{array}{l}\text { Age }>60 \\
\text { Preop mHHS }<50 \\
\text { Preop VAS }>7\end{array}$ & $\begin{array}{l}-2.6 \\
2.3\end{array}$ \\
\hline Sing et al $(9)^{c}$ & 2015 & 8,227 & $\begin{array}{l}\text { Age }>50 \\
\text { Osteoarthritis }\end{array}$ & $\begin{array}{l}- \\
-\end{array}$ \\
\hline Skendzel et al (6) & 2014 & 466 & $\begin{array}{l}\text { Space }<2 \mathrm{~mm} \\
\text { Alpha }>55 \text { degrees }\end{array}$ & $\begin{array}{l}10,8^{\mathrm{a}} \\
2.1^{\mathrm{a}}\end{array}$ \\
\hline Philippon et al (42) & 2013 & 96 & $\begin{array}{l}\text { Space }<2 \mathrm{~mm} \\
\text { Tönnis two-thirds }\end{array}$ & $\begin{array}{l}12 \\
4.8 \\
\end{array}$ \\
\hline Philippon et al (43) & 2012 & 153 & $\begin{array}{l}\text { Space }<2 \mathrm{~mm} \\
\text { Pre } \mathrm{mHHS}<60 \mathrm{p}\end{array}$ & $\begin{array}{l}14.6 \\
3.2\end{array}$ \\
\hline McCarthy et al (37) & 2011 & 106 & $\begin{array}{l}\text { Age }>40 \text { y } \\
\text { Outerbridge III/IV acetabular } \\
\text { Outerbridge III/IV femoral }\end{array}$ & $\begin{array}{l}3.6 \\
20 \\
58.1\end{array}$ \\
\hline Philippon et al (3) & 2009 & 122 & Space $<2 \mathrm{~mm}$ & 39 \\
\hline Total & - & 31,821 & & \\
\hline
\end{tabular}

Abbreviations: LCE, lateral center edge; mHHS, modified Harris Hip score; RR, relative risk; THA, total hip arthroplasty; VAS, visual analogue score. aRisk of having grade III/IV Outerbridge in surgery.

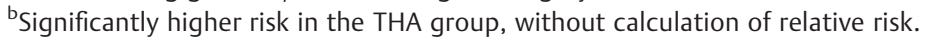

${ }^{\mathrm{c}} 86.9 \%$ of the cases belong to five papers with very long series. 
Table 2 Risk factors ordered from highest to lowest, according to the literature review

\begin{tabular}{|c|c|}
\hline Risk factors & Relative risk \\
\hline Chondropathy grade III/IV femoral & $\begin{array}{l}58.1(37) \\
12(45)\end{array}$ \\
\hline Articular space $<2 \mathrm{~mm}$ & $\begin{array}{l}39(3) \\
14.6(43) \\
12(42) \\
10.8(6) \\
4.26(40)\end{array}$ \\
\hline Chondropathy grade III/IV acetabular & $\begin{array}{l}20(37) \\
2.96(41)\end{array}$ \\
\hline Age & $\begin{array}{l}14.6(39) \\
4.65(36) \\
3.8(12) \\
3.6(37) \\
3.4(35) \\
3.18(11) \\
3.06(40) \\
1.06(41)\end{array}$ \\
\hline Tönnis 2 & $\begin{array}{l}7.73(44) \\
4.43(42) \\
3.1(45)\end{array}$ \\
\hline Obesity & $\begin{array}{l}5.6(35) \\
2.3(39)\end{array}$ \\
\hline Osteoarthritis & $\begin{array}{l}4.6(12) \\
3.8(11) \\
2.4(35)\end{array}$ \\
\hline LCE angle greater than 33 degrees & $4.6(50)$ \\
\hline Need to perform chondroplasty & $3.5(11)$ \\
\hline $\begin{array}{l}\text { mHHS value prior to surgery less } \\
\text { than } 60 \text { points }\end{array}$ & $\begin{array}{l}3.2(43) \\
2.6(38)\end{array}$ \\
\hline Acetabular microfractures needed & $2.86(40)$ \\
\hline Previous surgery & $\begin{array}{l}2.6(12) \\
2.4(41)\end{array}$ \\
\hline VAS preop greater than 7 & $2.3(38)$ \\
\hline$\alpha$ angle greater than 55 degrees & $2.1(6)$ \\
\hline Lacking surgical experience & $1.9(35)$ \\
\hline Female sex & $\begin{array}{l}1.8(35) \\
1.68(36)\end{array}$ \\
\hline Tobacco & $1.9(35)$ \\
\hline Need for acetabuloplasty & $1.8(41)$ \\
\hline
\end{tabular}

Abbreviations: LCE, lateral center edge; mHHS, modified Harris Hip score; VAS, visual analogue score.

\section{Discussion}

With this article the authors attempt to review the prognostic risk factors after a systematic review of the literature and the main published works.

Age is a prognostic factor. ${ }^{9,12,36-39}$ There is a higher conversion rate in older patients, ${ }^{11,36}$ with figures from 5.6 to $38.8 \%$ during the 1 st year and $>80 \%$ in the long term. ${ }^{6,9,22,36,37}$ Age as an isolated factor has been associated with an increased risk of conversion to THA. ${ }^{9,37,39,40}$ Patients older than 50 years have been associated with rates of 13 to $20 \%$ conversion in 1.6 to 2 years, ${ }^{9,12,42}$ although some studies have shown good results with that age although with shorter series (20 good results on 22 patients). ${ }^{46}$ Longer term series, at 8 and 10 years of follow-up, show rates of 37 to $38.8 \%$ in the group $>50$ years. ${ }^{36,37}$

Age over 60 is considered as an increased risk of THA from $3.4^{47}$ times to $14.33{ }^{39}$ The study by Kaldau et al shows that $87 \%$ of patients who converted to THA were older than 40 , while those who kept their hip preserved, only $46 \%$ were over $40 .^{34}$ In this same study, being 40 years old represents a $29 \%$ risk of leading to THA in a period of less than 8 years. ${ }^{34}$ Along these same lines, other studies have similar findings. $6,40,48$ The study by Domb et al presents better results, with a conversion rate to THA of $17.3 \%$ in those aged over $50 .{ }^{49}$ The study by Sing et $\mathrm{al}^{9}$ shows $16 \%$ of those over 50 with followup at 2 years, or Schairer et $\mathrm{al}^{39}$ with $12.4 \%$ THA also with more than 2 years of follow-up, although the conversion rate was lowest in patients aged younger than 40 years, with a relative risk of 5.48 , above 50 years places it at 8.97 , and above 60 years at $14.33 .{ }^{39}$ Some studies present as little as $4 \%$ with follow-up rates of 7 to 9 years. ${ }^{50}$ However, another study by Domb and colleagues ${ }^{38}$ in which the subgroup above 60 years old is analyzed, findings show a 30\% rate of prosthesis in just over a year, in the same way the knee studies also showed similar results. ${ }^{51}$

The female gender has been detected as a factor of greater risk in some works, although not with homogeneous results in all the reviewed works, ${ }^{37,45}$ presenting a risk of $1.68^{36}$ to $1.8^{35}$ compared with males.

An articular space of $<2 \mathrm{~mm}$ has been associated with joint pain ${ }^{40,52,53}$ and worse prognosis ${ }^{3,6}$ and hip arthroscopy has only shown a temporary improvement in these patients. ${ }^{7}$ Patients with a previous joint space of $<2 \mathrm{~mm}$ have shown $43 \%$ and 86 conversion rates to THA in less than 3 and 5 years, as opposed to 10 and $16 \%$ who have followed the same path if they presented an articular space $>2 \mathrm{~mm}$ in preoperative radiography. ${ }^{6,42,43}$ The presence of a reduced coxofemoral joint space on preoperative radiographs is associated with a 10.8-fold increased risk of presenting high-grade chondral lesions (Outerbridge III/IV) in arthroscopy, ${ }^{6}$ and an increase in the risk of conversion to THA of 39 times $^{3}$ (especially if the population is over 50 years old, where the risk rises 12 times ${ }^{42}$ ). The presence of an $\alpha$ angle $>55$ degrees increases the risk by 2.1 times. ${ }^{6,45}$

An acetabular coverage angle (Tonnis or Acetabular index) of less than 3 degrees $^{50}$ is an increased risk. A Wiberg angle (lateral center angle) $>33$ degrees increases the risk by 4.6 times, ${ }^{50}$ although another study finds that the risk is other way around, with a higher risk at lower angles. ${ }^{45}$ Hip osteoarthritis is one of the risk factors to consider. ${ }^{11,12,30,37,54,55}$ Cases with advanced osteoarthritis do not improve clinically with this procedure, although the initial phases may have a clinical benefit. $7,39,56,57$ The presence of degenerative changes classified as Tönnis two-thirds increases the risk of THA by 4.8 times. ${ }^{42}$ Another study warns of the risk even for patients with Tönnis 1 , especially in those over 50 where risk of THA is increased by 3.1 times. ${ }^{45}$ The Domb group observed a risk in 
Tönnis 2 patients to THA in 2 years of 7.73 with respect to Tönnis 0 and 4.36 with respect to Tönnis $1 .^{44}$

The progression of clinical pain and degenerative joint disease can lead to conversion to THA, which according to published studies is around 16 to $37 \%$ at 6 to 11 years followup. ${ }^{7,34,37,40,45,54}$ Different authors have conversion rates of 2.9 to $22.8 \%$ between 2 and 3 years after arthroscopy, ${ }^{27,30,39,54}$ with $63 \%$ joint survival rates at 10 years of follow-up. ${ }^{37,40}$ When we analyze how many of the patients who required THA presented osteoarthritis, we found that almost all of them had osteoarthritis of the hip. ${ }^{9}$ The presence of level 4 ALAD lesions, (associated with more than $80 \%$ of THA in patients in less than 2 years) may even suggest the conversion during an arthroscopy in the same surgical procedure. $^{38}$

In addition, conversions are usually early with a staggering 36\% of conversions occurring during the first 6 months, $60 \%$ in the first year and $100 \%$ of cases during the first 4 years. ${ }^{9,11,36,41,54}$ Patient data must be analyzed to assess whether the chosen surgery can or should be offered. ${ }^{58}$

Although the exact causes, ${ }^{22,37,58}$ are unknown, one of the factors to consider is both acetabular and femoral cartilage injury. ${ }^{34}$ A degree of Outerbridge injury, ${ }^{37,45,54,59}$ lesions of the chondrolabral complex (ALAD), ${ }^{38,45}$ or the need for cartilage treatment have shown a higher conversion rate $11,37,41$ in both the acetabulum and femoral head. ${ }^{34,40,45}$ Grade III/IV acetabular or femoral lesions have been described as factors of poor prognosis, increasing the possibility of ending up as a THA in less than 10 years with an increase of 20 and 58.1 times respectively, with femoral head injuries posing a greater threat than those of the acetabulum. ${ }^{37,45}$

The described factors have an obvious relationship. Chondropathy, loss of joint space, osteoarthritis, and a Tönnis 2 are expressions of joint degeneration. That is why the different studies that evaluate the different points of evolution show different degrees of risk. In a perspective study they can be taken into account in a global way.

There are also other risk factors to consider in light of this review. Tobacco use is related to an increased risk of 1.9. ${ }^{35}$ Obesity (body mass index $>30$ ) increases the risk from 2.43 to 5.6 times. $^{35,39,60-62}$

Both the surgeon's experience ( $<40$ hip arthroscopies annually) and centers with a lower hip arthroscopy volume, increase the risk of THA conversion, ${ }^{35}$ (1.9 times in lowvolume surgeons). In centers where at least 10 hip arthroscopies are performed per year, there is a reduced risk of THA conversion of $0.76 .^{39}$

In addition, the articles have shown how over time, rates of prosthesis are reduced, without necessarily reducing patient age. Schairer et $\mathrm{al}^{39}$ presented rates of prosthesis of $14.3 \%$ in 2005 while in 2010 they were $10.3 \%$ with significant differences. It is very likely that both experience and skill in the diagnosis and detection of the factors of poor prognosis have contributed to this decline, a point that will most likely see further improvement in the coming years.

Inflammatory arthritis is also an isolated risk factor for conversion to THA. ${ }^{63,64}$
The history of a previous hip arthroscopy, that is to say, hip re-arthroscopy increases the risk of conversion to THA by 2.6 times. $^{12}$

Regarding subjective assessment questionnaires such as visual analogue scale (VAS) pain level or modified Harris Hip score (mHHS), they have also shown their prognostic value. A preoperative value of $\mathrm{mHHS}$ below 50 points increases the risk of conversion to THA by 2.6 times, and below 60 points in a population over 50 years increases by 3.2 times. ${ }^{43}$ If a VAS greater than 7 the risk is 2.3 times higher. ${ }^{38}$

The combination of some of those factors is really surprising. The combination of age and cartilage lesions may have a high prognostic component. Age below 40 years and (I/II) Outerbridge injuries are related to a $10 \%$ rate of prosthesis at 10 years follow-up, while $>40$ years and Outerbridge III/IV at 10 years has a rate of prosthesis of $99 \% .{ }^{37}$

The present study has several limitations to take into account. This is a review, which, despite being systematic, may contain bias in its search and combination of terms. To reduce this limitation we have followed the steps that can be observed in the flowchart.

Second, the articles reviewed present a very different number of patients. Series of highly expert groups in this type of surgery have been collected with reviews of global databases that mix the results of different groups with differences in their level of experience. That is why the results may differ. The work of expert teams is normally associated with the great experience of the leader of that group, while data reviews could offer a more homogeneous photograph of a larger segment of surgeons.

Third, we have detected that many of the variables could be superimposable. A reduced space and Tonnis 2, grade 3 to 4 chondropathy and osteoarthritis could be synonymous terms and they may share a high percentage of similarities in the eyes of most observers.

\section{Conclusion}

Based on the review we observed that the elements that are most associated with a conversion to THA after a hip arthroscopy are high grades of femoral and acetabular chondropathy, reduced joint space below $2 \mathrm{~mm}$, older age, Tönnis 2, obesity, and hip osteoarthritis.

\section{Conflict of Interest}

The authors report no conflict of interest.

\section{References}

1 Altman R, Alarcón G, Appelrouth D, et al. The American College of Rheumatology criteria for the classification and reporting of osteoarthritis of the hip. Arthritis Rheum 1991;34(05):505-514

2 Kemp JL, MacDonald D, Collins NJ, Hatton AL, Crossley KM. Hip arthroscopy in the setting of hip osteoarthritis: systematic review of outcomes and progression to hip arthroplasty. Clin Orthop Relat Res 2015;473(03):1055-1073

3 Philippon MJ, Briggs KK, Yen Y-M, Kuppersmith DA. Outcomes following hip arthroscopy for femoroacetabular impingement with associated chondrolabral dysfunction: minimum two-year follow-up. J Bone Joint Surg Br 2009;91(01):16-23 
4 Agricola R, Heijboer MP, Bierma-Zeinstra SMA, Verhaar JAN, Weinans H, Waarsing JH. Cam impingement causes osteoarthritis of the hip: a nationwide prospective cohort study (CHECK). Ann Rheum Dis 2013;72(06):918-923

$5 \mathrm{Ng}$ VY, Ellis TJ. More than just a bump: cam-type femoroacetabular impingement and the evolution of the femoral neck. Hip Int 2011;21(01):1-8

6 Skendzel JG, Philippon MJ, Briggs KK, Goljan P. The effect of joint space on midterm outcomes after arthroscopic hip surgery for femoroacetabular impingement. Am J Sports Med 2014;42(05): 1127-1133

7 Olach M, Gerhard P, Giesinger K, Lampert C, Erhardt JB. Clinical and radiological outcome at mean follow-up of 11 years after hip arthroscopy. Arch Orthop Trauma Surg 2019;139:1-6

8 Bozic KJ, Chan V, Valone FH III, Feeley BT, Vail TP. Trends in hip arthroscopy utilization in the United States. J Arthroplasty 2013; 28(Suppl 8):140-143

9 Sing DC, Feeley BT, Tay B, Vail TP, Zhang AL. Age-related trends in hip arthroscopy: a large cross-sectional analysis. Arthroscopy 2015;31(12):2307-2313.e2

10 Palmer AJR, Malak TT, Broomfield J, et al. Past and projected temporal trends in arthroscopic hip surgery in England between 2002 and 2013. BMJ Open Sport Exerc Med 2016;2(01):e000082

11 Bedard NA, Pugely AJ, Duchman KR, Westermann RW, Gao Y, Callaghan JJ. When Hip Scopes Fail, They Do So Quickly. J Arthroplasty 2016;31(06):1183-1187

12 McCarthy B, Ackerman IN, de Steiger R. Progression to total hip arthroplasty following hip arthroscopy. ANZ J Surg 2018; 88:702-706

13 Byrd JWT, Jones KS, Gwathmey FW. Femoroacetabular impingement in adolescent athletes: outcomes of arthroscopic management. Am J Sports Med 2016;44(08):2106-2111

14 Horisberger M, Brunner A, Herzog RF. Arthroscopic treatment of femoral acetabular impingement in patients with preoperative generalized degenerative changes. Arthroscopy 2010;26(05): 623-629

15 Murphy M, Kemp J, Smith A, Charlesworth J, Briffa K. Clinical measures of hip range of motion do not correlate with the degree of cam morphology in semi-elite Australian Footballers: a crosssectional study. Int J Sports Phys Ther 2017;12(07):1078-1086

16 McDonald JE, Herzog MM, Philippon MJ. Performance outcomes in professional hockey players following arthroscopic treatment of FAI and microfracture of the hip. Knee Surg Sports Traumatol Arthrosc 2014;22(04):915-919

17 Bedi A, Galano G, Walsh C, Kelly BT. Capsular management during hip arthroscopy: from femoroacetabular impingement to instability. Arthroscopy 2011;27(12):1720-1731

18 Ilizaliturri VM. Endoscopic treatment of snapping hips iliotibial band, and iliopsoas tendon. 2010;18:120-127

19 Helenius I, Tanskanen P, Haapala J, et al. Hip arthroscopy in osteoarthritis. A review of 68 patients. Ann Chir Gynaecol 2001;90(01):28-31

20 Stevens MS, Legay DA, Glazebrook MA, Amirault D. The evidence for hip arthroscopy: grading the current indications. Arthroscopy 2010;26(10):1370-1383

21 Sansone M, Ahldén M, Jónasson P, et al. Outcome after hip arthroscopy for femoroacetabular impingement in 289 patients with minimum 2-year follow-up. Scand J Med Sci Sports 2017;27 (02):230-235

22 Byrd JWT, Jones KS. Prospective analysis of hip arthroscopy with 10-year follow-up. Clin Orthop Relat Res 2010;468(03):741-746

23 Londers J, Van Melkebeek J. Hip arthroscopy: outcome and patient satisfaction after 5 to 10 years. Acta Orthop Belg 2007;73(04): 478-483

24 Fukui K, Briggs KK, Trindade CAC, Philippon MJ. Outcomes after labral repair in patients with femoroacetabular impingement and borderline dysplasia. Arthroscopy 2015;31(12):2371-2379
25 Gupta A, Redmond JM, Hammarstedt JE, Schwindel L, Domb BG. Safety measures in hip arthroscopy and their efficacy in minimizing complications: a systematic review of the evidence. Arthroscopy 2014;30(10):1342-1348

26 Harris JD, McCormick FM, Abrams GD, et al. Complications and reoperations during and after hip arthroscopy: a systematic review of 92 studies and more than 6,000 patients. Arthroscopy 2013;29(03):589-595

27 Kowalczuk M, Bhandari M, Farrokhyar F, et al. Complications following hip arthroscopy: a systematic review and meta-analysis. Knee Surg Sports Traumatol Arthrosc 2013;21(07): 1669-1675

28 Philippon M, Schenker M, Briggs K, Kuppersmith D. Femoroacetabular impingement in 45 professional athletes: associated pathologies and return to sport following arthroscopic decompression. Knee Surg Sports Traumatol Arthrosc 2007;15(07): 908-914

29 Souza BGSE, Dani WS, Honda EK, et al. Do complications in hip arthroscopy change with experience? Arthroscopy 2010;26(08): 1053-1057

30 Herrmann SJ, Bernauer M, Erdle B, Südkamp NP, Helwig P, Hauschild $O$. Osteoarthritic changes rather than age predict outcome following arthroscopic treatment of femoroacetabular impingement in middle-aged patients. BMC Musculoskelet Disord 2016; 17:253

31 Ward JP, Rogers P, Youm T. Failed hip arthroscopy: causes and treatment options. Orthopedics 2012;35(07):612-617

32 McCarthy JC, Lee JA. Arthroscopic intervention in early hip disease. Clin Orthop Relat Res 2004;(429):157-162

33 O'leary JA, Berend K, Vail TP. The relationship between diagnosis and outcome in arthroscopy of the hip. Arthroscopy 2001;17(02): $181-188$

34 Kaldau NC, Brorson S, Hölmich P, Lund B. Good midterm results of hip arthroscopy for femoroacetabular impingement. Dan Med J 2018;65(06):4-8

35 Kester BS, Capogna B, Mahure SA, Ryan MK, Mollon B, Youm T. Independent risk factors for revision surgery or conversion to total hip arthroplasty after hip arthroscopy: a review of a large statewide database from 2011 to 2012. Arthroscopy 2018;34(02): 464-470

36 Malviya A, Raza A, Jameson S, James P, Reed MR, Partington PF. Complications and survival analyses of hip arthroscopies performed in the national health service in England: a review of 6,395 cases. Arthroscopy 2015;31(05):836-842

37 McCarthy JC, Jarrett BS BT, Ojeifo OB, Ann Lee JM, Bragdon CR. What factors influence long-term survivorship after hip arthroscopy? Clin Orthop Rel Res 2011;469(02):362-371

38 Redmond JM, Gupta A, Cregar WM, Hammarstedt JE, Gui C, Domb BG. Arthroscopic treatment of labral tears in patients aged 60 years or older. Arthroscopy 2015;31(10):1921-1927

39 Schairer WW, Nwachukwu BU, McCormick F, Lyman S, Mayman D. Use of hip arthroscopy and risk of conversion to total hip arthroplasty: a population-based analysis. Arthroscopy 2016;32 (04):587-593

40 Menge TJ, Briggs KK, Dornan GJ, McNamara SC, Philippon MJ. Survivorship and outcomes 10 years following hip arthroscopy for femoroacetabular impingement: labral debridement compared with labral repair. J Bone Joint Surg Am 2017;99(12):997-1004

41 Redmond JM, Gupta A, Dunne K, Humayun A, Yuen LC, Domb BG. What factors predict conversion to THA after arthroscopy? Clin Orthop Relat Res 2017;475(10):2538-2545

42 Philippon MJ, Briggs Mph KK, Carlisle JC, Patterson Ba DC. Joint space predicts THA after hip arthroscopy in patients 50 years and older. Clin Orthop Relat Res 2013;471(08):2492-2496

43 Philippon MJ, Schroder E Souza BG, Briggs KK, Briggs KK. Hip arthroscopy for femoroacetabular impingement in patients aged 50 years or older. Arthroscopy 2012;28(01):59-65 
44 Chandrasekaran S, Darwish N, Gui C, Lodhia P, Suarez-Ahedo C, Domb BG. Outcomes of hip arthroscopy in patients with Tönnis Grade-2 osteoarthritis at a mean 2-year follow-up: evaluation using a matched-pair analysis with Tönnis Grade- 0 and Grade- 1 cohorts. J Bone Joint Surg Am 2016;98(12):973-982

45 Perets I, Chaharbakhshi EO, Mu B, et al. Hip arthroscopy in patients ages 50 years or older: minimum 5-year outcomes, survivorship, and risk factors for conversion to total hip replacement. Arthroscopy 2018;34(11):3001-3009

46 Ben Tov T, Amar E, Shapira A, Steinberg E, Atoun E, Rath E. Clinical and functional outcome after acetabular labral repair in patients aged older than 50 years. Arthroscopy 2014;30(03):305-310

47 Capogna BM, Ryan MK, Begly JP, Chenard KE, Mahure SA, Youm T. Clinical outcomes of hip arthroscopy in patients 60 or older: a minimum of 2-year follow-up. Arthroscopy 2016;32(12): 2505-2510

48 Comba F, Yacuzzi C, Ali PJ, Zanotti G, Buttaro M, Piccaluga F. Joint preservation after hip arthroscopy in patients with FAI. Prospective analysis with a minimum follow-up of seven years. Muscles Ligaments Tendons J 2016;6(03):317-323

49 Domb BG, Linder D, Finley Z, et al. Outcomes of hip arthroscopy in patients aged 50 years or older compared with a matched-pair control of patients aged 30 years or younger. Arthroscopy 2015; 31(02):231-238

50 Haefeli PC, Albers CE, Steppacher SD, Tannast M, Büchler L. What are the risk factors for revision surgery after hip arthroscopy for femoroacetabular impingement at 7-year follow-up? Clin Orthop Relat Res 2017;475(04):1169-1177

51 Jameson SS, Rushton SP, Dowen D, et al. Increasing age and female gender are associated with early knee replacement following arthroscopy. Knee Surg Sports Traumatol Arthrosc 2014;22(11): 2665-2671

52 Gosvig KK, Jacobsen S, Palm H, Sonne-Holm S, Magnusson E. A new radiological index for assessing asphericity of the femoral head in cam impingement. J Bone Joint Surg Br 2007;89(10): 1309-1316

53 Jacobsen S, Sonne-Holm S, Søballe K, Gebuhr P, Lund B. The relationship of hip joint space to self reported hip pain. A survey of 4.151 subjects of the Copenhagen City Heart Study: the Osteoarthritis Substudy. Osteoarthritis Cartilage 2004;12(09): 692-697

54 Haviv B, O'Donnell J. The incidence of total hip arthroplasty after hip arthroscopy in osteoarthritic patients. Sports Med Arthrosc Rehabil Ther Technol 2010;2:18

55 Javed A, O'Donnell JM. Arthroscopic femoral osteochondroplasty for cam femoroacetabular impingement in patients over 60 years of age. J Bone Joint Surg Br 2011;93(03):326-331

56 Byrd JWT, Jones KS. Hip arthroscopy for labral pathology: prospective analysis with 10-year follow-up. Arthroscopy 2009;25 (04):365-368

57 Ganz R, Parvizi J, Beck M, Leunig M, Nötzli H, Siebenrock KA. Femoroacetabular impingement: a cause for osteoarthritis of the hip. Clin Orthop Relat Res 2003;(417):112-120

58 Bogunovic L, Gottlieb MSW M, Pashos GB, Baca GB, Clohisy JC. Why do hip arthroscopy procedures fail? Clin Orthop Relat Res 2013;471:2523-2529

59 Larson CM, Giveans MR. Arthroscopic debridement versus refixation of the acetabular labrum associated with femoroacetabular impingement. Arthroscopy 2009;25(04):369-376

60 Bech NH, Kodde IF, Dusseldorp F, Druyts PAMC, Jansen SPL, Haverkamp D. Hip arthroscopy in obese, a successful combination? J Hip Preserv Surg 2015;3(01):37-42

61 Onyekwelu I, Glassman SD, Asher AL, Shaffrey CI, Mummaneni PV, Carreon LY. Impact of obesity on complications and outcomes: a comparison of fusion and nonfusion lumbar spine surgery. J Neurosurg Spine 2017;26(02):158-162

62 Woon CYL, Piponov H, Schwartz BE, et al. Total knee arthroplasty in obesity: in-hospital outcomes and national trends. J Arthroplasty 2016;31(11):2408-2414

63 Anderson LA, Peters CL, Park BB, Stoddard GJ, Erickson JA, Crim JR. Acetabular cartilage delamination in femoroacetabular impingement. Risk factors and magnetic resonance imaging diagnosis. J Bone Joint Surg Am 2009;91(02):305-313

64 Jerosch J, Schunck J, Khoja A. Arthroscopic treatment of the hip in early and midstage degenerative joint disease. Knee Surg Sports Traumatol Arthrosc 2006;14(07):641-645 